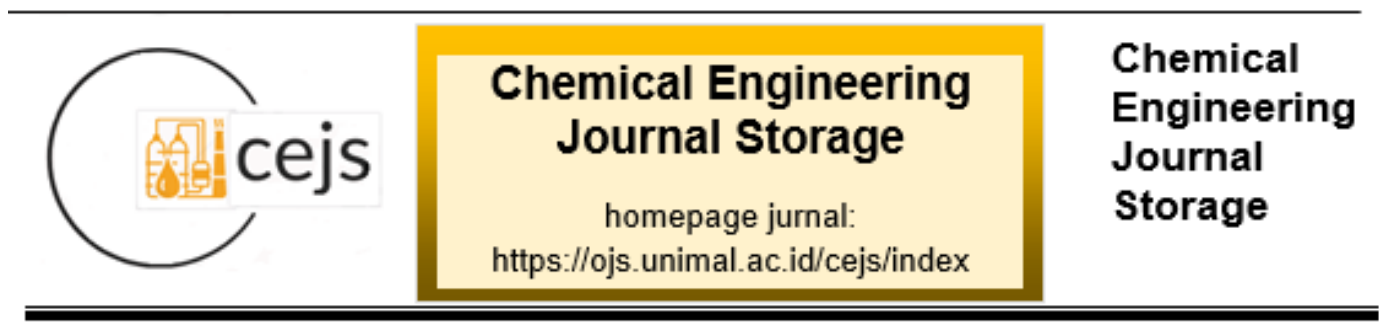

\title{
PEMANFAATAN EKSTRAK DAUN RAMBUTAN (Nephelium lappaceum) SEBAGAI INHIBITOR KOROSI PADA PLAT BESI (STEEL) DALAM MEDIA AIR LAUT
}

\author{
Yopi Aji Akbar, Ishak*, Zulnazri, Rozanna Dewi, Rizka Nurlaila \\ Jurusan Teknik Kimia, Fakultas Teknik, Universitas Malikussaleh \\ Kampus Utama Cot Teungku Nie Reuleut, Muara Batu, Aceh Utara - 24355 \\ Korespondensi: +62 813-6290-8162, e-mail:Ishak@unimal.ac.id
}

\begin{abstract}
Abstrak
Korosi adalah proses perusakan pada permukaan logam yang disebabkan oleh terjadinya reaksi kimia (reaksi elektrokimia) pada permukaan logam. Untuk mengurangi laju korosi bisa dengan menambahkan inhibitor alami salah satunya daun rambutan yang mengandung tanin sehingga dapat membentuk senyawa komplek dengan Fe(III) di permukaan logam, sehingga laju reaksi korosi akan mengalami penurunan. Studi penggunaan ekstrak daun rambutan sebagai inhibitor korosi pada plat besi akan dilakukan secara eksperimen murni di laboratorium dengan menggunakan metode perendaman. Media korosif untuk perendaman digunakan air laut yang telah ditambahkan inhibitor. Inhibitor yang digunakan yaitu inhibitor organik yang diambil dari ekstrak daun rambutan. Perendaman dilakukan dalam interval waktu (3, 6, 9, 12, dan 15) hari dengan konsentrasi inhibitor (0, 50, 100, dan 150) ppm. Hasil pengujian menunjukkan bahwa serangan korosi terjadi secara merata dipermukaan logam, Besarnya laju korosi dinyatakan sebagai besarnya kehilangan berat benda uji per satuan luas permukaan per satuan waktu perendaman. Dari hasil penelitian diperoleh bahwa laju korosi plat besi dalam lingkungan air laut menurun secara segnifikan dengan meningkatnya konsentrasi ekstrak daun rambutan dan waktu perendaman. Penurunan ini akibat pembentukan lapisan tipis dipermukaan plat besi, sehingga menghambat kontak langsung antara plat besi dan lingkungan. Efesiensi inhibisi tertinggi diperoleh pada perendaman 15 hari dengan konsentrasi 150 ppm yaitu $96 \%$
\end{abstract}

Kata Kunci: Daun Rambutan, Inhibitor, Laju Korosi dan Tanin,

\section{Pendahuluan}

Korosi merupakan fenomena kimia yang terjadi pada bahan logam di berbagai kondisi lingkungan. Proses korosi secara alami sangat sulit dihindari, 
salah satu usaha yang dapat dilakukan adalah melakukan pencegahan. Salah satu pencegahan yang dapat dilakukan adalah penggunaan inhibitor. Inhibitor yang dapat digunakan adalah tanin. Tanin dapat berfungsi sebagai zat anti korosi. Tanin banyak terdapat pada bagian dari tumbuhan. Penelitian yang telah dilakukan yaitu dengan mengekstraksi bagian dari tumbuhan tersebut agar zat tanin yang terkandung di dalamnya dapat keluar dan dapat berfungsi sebagai inhibitor korosi (Mulyati, 2019)

Peristiwa korosi sering dijumpai dalam kehidupan sehari-hari dan tanpa di sadari begitu dekat dengan kehidupan kita, misalnya paku berkarat, tiang listrik berkarat pagar rumah berkarat dan sebagainya. Peristiwa korosi mengakibatkan degradasi material, khususnya logam menjadi senyawa yang kurang bermanfaat.

Di industri penanganan korosi pada peralatsan produksi harus dilakukan dengan baik, mengingat besarnya kerugian yang harus di tanggung oleh perusahaan apa bila korosi dibiarkan begitu saja, seperti terhentinya proses produksi akibat kerusakan instalasi produksi atau adanya kecelakaan dan pencemaran lingkungan akibat bocornya salah satu sistem instalasi produksi. Di Indonesia negara menganggarkan 1-1,5\% dari GDP (Grass Domestik Production) atau hampir triliun rupiah dana yang dianggarkan untuk menangi masalah korosi.

Salah satu cara menghambat korosi adalah dengan penambahan inhibitor. Inhibitor adalah suatu senyawa kimia yang dalam jumlah kecil tetapi mampu menghambat reaksi korosi logam baja dengan lingkungannya. Dapat juga dikatakan bahwa inhibitor membentuk lapisan protektif dipermukaan logam dengan reaksi antara larutan dan permukaan logam. Sejauh ini penggunaan inhibitor merupakan salah satu cara yang efektif untuk mencegah korosi, karena prosesnya yang sederhana dan biaya yang murah. Senyawa yang dapat digunakan sebagai inhibitor mengandung oksigen, nitrogen, sulfur, fosfor dan senyawa ikatan rangkap. Pada umumnya semakin besar konsentrasi inhibitor, maka semakin efektif dalam menurunkan korosi pada logam.

Senyawa kimia sintetis untuk inhibitor seperti asam stearat dan imidazolin stearat yang di teliti oleh Xiuyu Liu et.al. merupakan inhibitor yang cukup baik untuk mengurangi laju korosi pada besi dalam larutan asam klorida. 
Namun demikian, pada kenyataannya bahan kimia sintetis ini merupakan bahan kimia yang berbahaya, harganya cukup mahal, dan tidak ramah lingkungan. Untuk itu diperlukan adanya inhibitor yang aman,mudah didapatkan,bersifat biodegradable,biaya murah,dan ramah lingkungan. Hal ini bisa diwujudkan dengan melakukan penelitian terhadap bahan-bahan alam yang pada umumnya bersifat ramah lingkungan untuk digunakan sebagai inhibitor. Beberapa penelitian menunjukkan bahwa ekstrak bahan alam dapat digunakan untuk menurunkan laju korosi logam. Bagian tanaman yang dapat digunakan sebagai inhibitor korosi diantaranya terdapat pada bagian daun, biji, kulit atau kombinasi biji dan daun. Proses ekstrak bahan alami ini dapat dilakukan dengan beberapa metode seperti maserasi, infundasi, digesti, perkolasi dan sokletasi.

Dari penelitian terdahulu, kulit pisang kepok menjadi salah satu alternatif inhibitor korosi. Kulit pisang kepok merupakan salah satu tanaman yang digunakan sebagai inhibitor alami karena kulit buah pisang kepok tergolong jenis tanin terkondensasi yang dapat menghambat laju korosi (Mulyati, 2019), Ekstrak kulit jeruk dan kulit mangga telah diteliti (Noor et al., 2015) dapat menurunkan laju korosi logam API 5L Gr B dalam larutan $\mathrm{NaCl}$. Hal ini ditunjukkan dengan adanya kandungan asam 12-bromolauric 8,14\% dan asam hexadecanoic 4,30\% yang dapat membentuk lapisan tipis pada permukaan logam. Lapisan tipis ini telah menekan laju korosi sebesar 0,60 mpy dan untuk kulit mangga konsentrasi 600 ppm didapatkan laju korosi sebesar 1,0 mpy. Penamabahan ekstrak kulit buah naga merah berpengaruh terhadap $\mathrm{pH}$ larutan, jika volume larutan dari inhibitor kulit buah naga merah semakin banyak maka hal tersebut dapat lebih efisien untuk menghambat laju korosi (Bushan et al., 2017).

Beberapa bahan alami yang memiliki senyawa tersebut diantaranya yaitu daun rambutan, daun rambutan mengandung senyawa saponin dan tanin. Tanin adalah senyawa organik non toksik yang tergolong folifenol yang bisa diperoleh dari ektrak tumbuhantumbuhan. Tanin adalah salah satu senyawa yang mempunyai gugus hidroksi. Gugus hidroksi dapat berikatan dengan logam untuk membentuk senyawa komplek pada permukaan baja, sehingga tanin dapat 
berfungsi sebagai zat anti korosi. Tanin memiliki kemampuan mengendapkan protein, mengkelat logam, menyamakan kulit dan juga sebagai zat warna

Selain daripada itu, daun rambutan merupakan bahan alami yang mudah didapat dan relatif murah sehingga berpotensi untuk diproduksi secara massal. Sebagian besar penelitian menunjukkan bahwa perilaku inhibisi korosi dilakukan pada media asam. Hal ini disebabkan pada media asam tersebut logam lebih mudah terkorosi jika dibandingkan pada media alkali/basa. Selain itu, proses inhibisi yang bersifat dua arah menuntut adanya suatu konsentrasi minimum dari inhibitor sehingga pelapisan permukaan logam tetap terjaga.

Berdasarkan uraian diatas, maka perlu dilakukan penelitian lebih lanjut mengenai ekstrak terhadap bahan-bahan alam sebagai inhibitor. Pada penelitian ini dilakukan ekstrak terhadap daun rambutan sebagai penghambat laju korosi plat besi (Steel) dalam media air laut. Daun rambutan mengandung vitamin (A dan C), karotenoid, flavonoid, tannin, alkaloid, kalsium, fosfor, magnesium, besi, natrium dan enzim bromelin. Tannin merupakan senyawa aktif metabolit sekunder yang diketahui mempunyai beberapa khasiat yaitu sebagai astringen, anti diare, anti bakteri dan antioksidan.

\section{Bahan dan Metode}

Adapun bahan yang digunakan dalam penelitian sebagai berikut, $\mathrm{NaCl}$ $2 \% 1 \mathrm{ml}$, etanol $400 \mathrm{ml}$, daun rambutan $100 \mathrm{gr}$, (daun rambutan : etanol =1:4), air laut $1600 \mathrm{ml}, \mathrm{FeCl}_{3} 5 \% 1 \mathrm{ml}$, , HCL 0,1 N, amplas grade 600 dan aquades. dan peralatan yang diperlukan dalam penelitian ini antara lain adalah, alat pemotong sampel, timbangan digital, jangka sorong, rotary vacum evaporator, magnetik stirer, benang dan kertas label, oven , kertas amplas grade 600, beaker glass dan labu erlenmeyer $1000 \mathrm{ml}$, gelas ukur, corong, wadah plastik, labu ukur $250 \mathrm{ml}$, kertas saring.

Penelitian ini terdiri dari tiga tahap yang pertama yaitu preparasi bahan uji, sebelum melakukan penelitian kita terlebih dahulu mempersiapkan bahan uji yang dibutuhkan seperti memotong plat besi sesuai dengan ukuran yang diperlukan, setelah itu dihalukan dengan amplas, kemudian direndam selama 2 
menit, lalu dikeringkan dalam oven dan didinginkan dalam desikator kemudian diukur kembali luas yang sebenarnya, lalu ditimbang.

Pembuatan ekstrak daun rambutan dilakukan dengan metode maserasi, dan ekstrasi dilakukan dengan mencampurkan daun rambutan kering dengan etanol 80\% dengan perbandingan 1:4 ( 100 gr daun rambutan : $400 \mathrm{ml}$ etanol) dan dilakukan selama 2 x 24 jam dengan cara direndam dalam beaker glass kemudian ditutup dengan alumunium foil. Hasil ekstraksi disaring untuk memisahkan filtrat dari endapannya, ekstrak yang diperoleh dilakukan pengujian untuk mengetahui tanin yang di peroleh. Filtrat yang dihasilkan kemudian dievaporasi menggunakan rotari evaporator dengan suhu $90^{\circ} \mathrm{C}$ dan kecepatan $60 \mathrm{rpm}$ untuk memisahkan ekstrak dari pelarutnya. Filtrat digunakan sebagai ekstrak daun rambutan yang menjadi inhibitor organik (Setyowati et al., 2020). Konsesntrasi inhibitor yang digunakan dalam penelitian ini menggunakan satuan part per million (ppm) sebesar $(0,50,100,150)$ ppm dengan variasi waktu $(3,6,9,12,15)$ hari.

Persiapan larutan korosif yang akan digunakan adalah air laut yang berasal dari laut pantai pulo seumadu, Kecamatan Banda Sakti, Kota Lhokseumawe. Air laut sebanyak $80 \mathrm{ml}$ diisi dalam beaker glass, lalu dimasukan dalam wadah dan ditambahkan plat besi yang sudah direndamkan inhibitor sesuai konsentrasi yang diinginkan.

Pengujian sampel dilakukan untuk mengetahui apakah bahan yang kita gunakan dapat dijadikan sebagai inhibitor korosi atau tidak. Yaitu dengan cara direndam dalam larutan korosif yang telah dipersiapkan, Plat besi (Steel) yang telah diukur luas permukaannya lalu ditimbang dan dicatat, kemudian Plat besi (Steel) direndam dalam larutan korosif yang telah ditambahkan inhibitor, konsentrasi inhibitor dan waktu perendaman dilakukan sesuai dengan variabel yang divariasikan. Setelah waktu perendaman tercapai, plat besi (Steel) sebagai bahan uji dicuci dengan larutan HCL 0,1 N untuk menghilangkan produk korosi yang menempel lalu dibilas dengan aquades, plat besi (Steel) yang sudah bersih selanjutnya dikeringkan dengan oven, kemudian didinginkan dalam desikator lalu dilakukan penimbangan dan dicatat perubahan berat yang terjadi, perlakuan dilakukan sebanyak 4 kali ulangan. Data yang dihitung adalah laju korosi tanpa 
penambahan inhibitor serta penambahan inhibitor dan efisiensi inhibitor itu sendiri. (Hermawan et al., 2012)

\section{Hasil dan Pembahasan}

3.1 Uji tanin

Dari hasil analisa uji tanin yang telah dilakukan pada daun rambutan, diketahui bahwa daun rambutan mengandung senyawa tanin. Hal ini ditunjukan dengan adanya berwarna biru hitam ketika ekstrak daun rambutan ditambah dengan $\mathrm{FeCl}_{3}$, itu terjadi karena adanya reaksi $\mathrm{FeCl}_{3}$ melibatkan struktur tanin yang merupakan senyawa polifenol, dimana dengan adanya gugus fenol akan berikatan dengan $\mathrm{FeCl}_{3}$ membentuk kompleks berwarna biru kehitaman. Untuk menguatkan uji tanin secara kualitatif, ekstrak daun rambutan juga di uji dengan Gelatin test, dan hasil analisa yang didapatkan adanya endapan putih yang menunjukkan ada tanin didalam ekstrak daun rambutan. Hal ini sesuai dengan penelitian yang dilakukan oleh (Pratama et al., 2019) apabila ekstrak mengandung tanin maka akan terbentuk warna hitam kebiruan dan jika ditambahkan gelatin terbentuknya endapan putih.

Adapun hubungan waktu perendaman terhadap laju korosi dapat dilihat pada grafik 3.1 berikut.

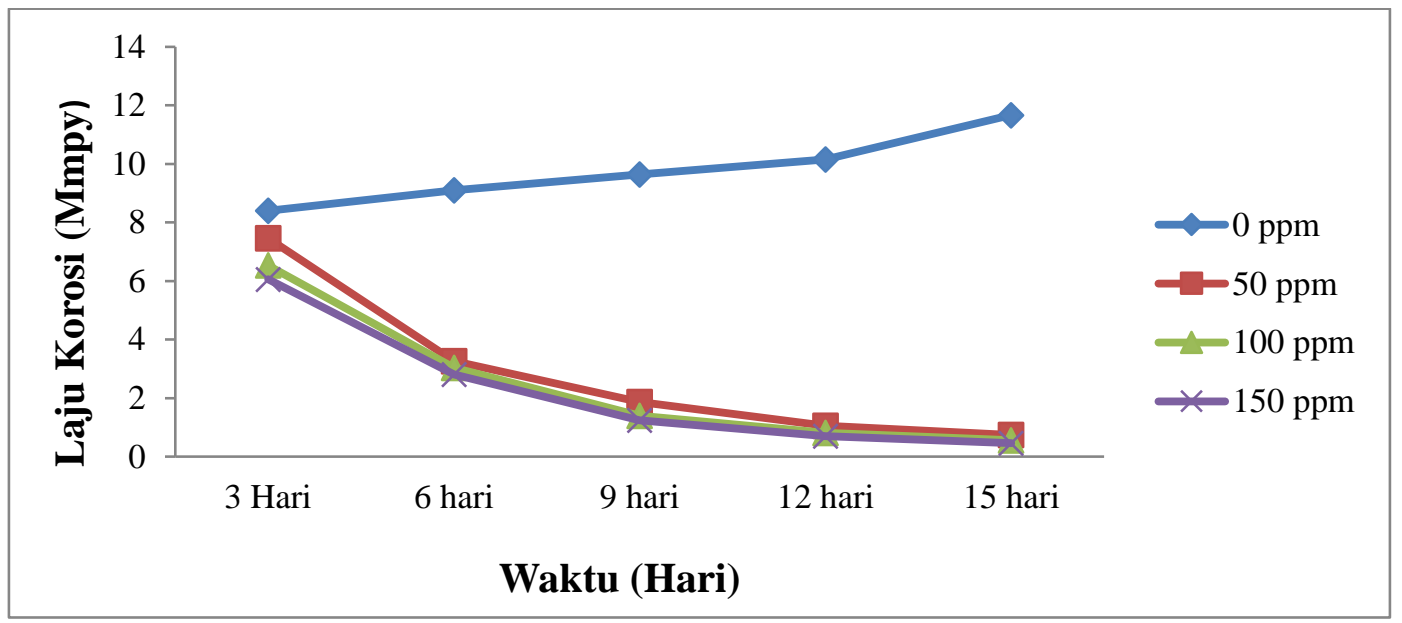

Gambar 3.1 Pengaruh Waktu Perendaman Terhadap Laju Korosi

Laju korosi baja dalam lingkungan air laut menurun dengan meningkat konsentrasi ekstrak daun rambutan dan waktu perendaman. Dalam waktu 
perendaman dari 3 hari sampai 15 hari menunjukkan bahwa penurunan laju korosi masih relatif cepat. Hal ini terjadi karena semakin meningkat konsentrasi daun rambutan semakin cepat daya serap pada baja mengakibatkan laku korosi menurun. Demikian juga dengan waktu perendaman, semakin lama ekstrak daun rambutan direndam dengan baja semakin besar jumlah ekstrak daun rambutan yang mekindungi baja sehingga mengakibatkan penurunan laju korosi. Inhibitor ekstrak daun rambutan mempengaruhi seluruh permukaan logam yang terkorosi jika konsentrasi nya mencukupi. Inhibitor ini membentuk lapisan tipis pada permukaan logam sehingga melindungi logam. Dari data yang didapat menunjukkan bahwa penggunaan inhibitor ini cukup efektif, karena bisa menunjukkan laju korosi secara cepat.

Adapun hubungan waktu perendaman terhadap efisiensi inhibisi dapat dilihat pada grafik 3.2 berikut.

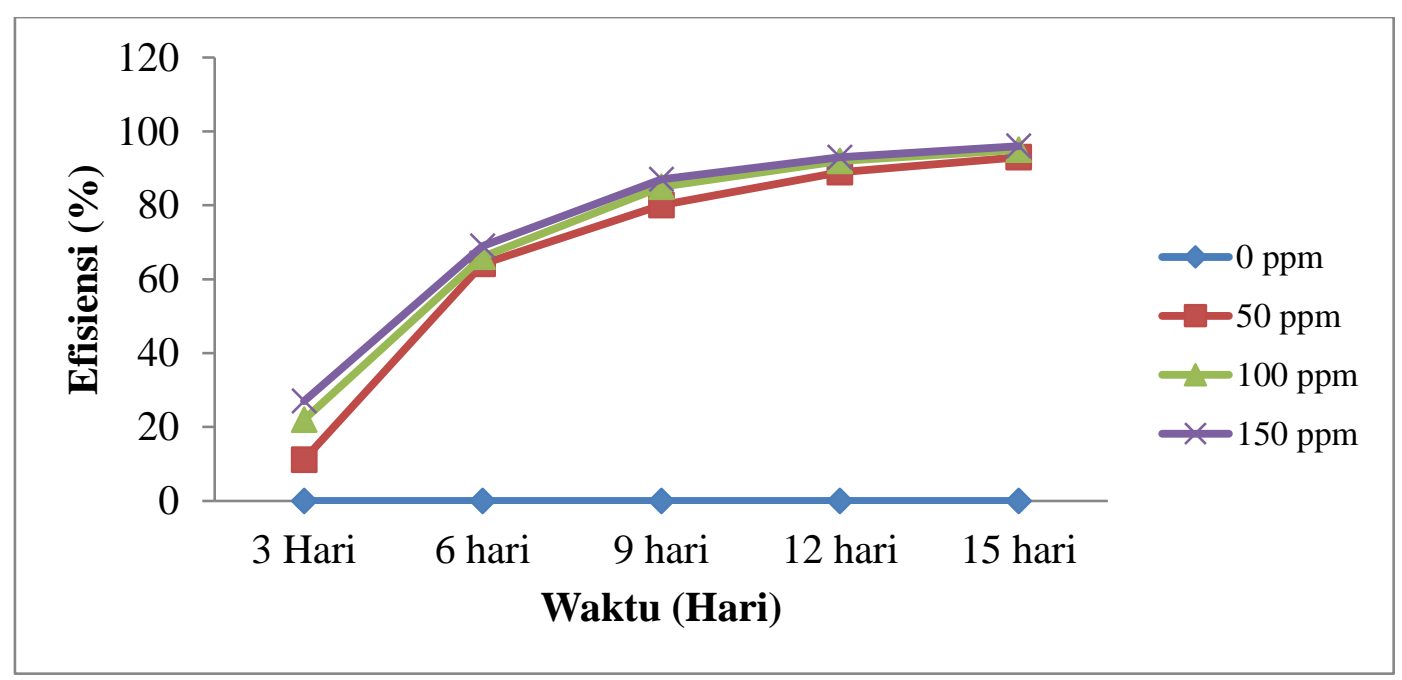

Gambar 3.2 Pengaruh Waktu Perendaman Terhadap Efisiensi Inhibisi

Gambar 3.2 menunjukkan bahwa efisiensi inhibisi ekstrak daun rambutan meningkat dengan meningkatnya konsentrasi dan waktu perendaman. Makin lama waktu perendaman makin tinggi efisien yang didapat maka laju korosi pada baja akan semakin lambat. Pada perendaman 3 hari efisiensi tertinggi didapat pada ekstrak daun rambutan dengan konsetrasi 150 ppm yaitu sebanyak 27\% dan efisiensi terendah didapat pada ekstrak daun rambutan dengan konsentrasi 50 ppm sebesar. 11,19\%. Pada perendaman 6 hari efisiensi tertinggi didapat pada ekstrak 
daun rambutan dengan konsetrasi 150 ppm yaitu sebanyak 69\% dan efisiensi terendah didapat pada ekstrak daun rambutan dengan konsentrasi 50 ppm sebesar. 64,17\%. Pada perendaman 9 hari efisiensi tertinggi didapat pada ekstrak daun rambutan dengan konsetrasi 150 ppm yaitu sebanyak 87\% dan efisiensi terendah didapat pada ekstrak daun rambutan dengan konsentrasi 50 ppm sebesar $80 \%$. Pada perendaman 12 hari efisiensi tertinggi didapat pada ekstrak daun rambutan dengan konsetrasi 150 ppm yaitu sebanyak 93\% dan efisiensi terendah didapat pada ekstrak daun rambutan dengan konsentrasi 50 ppm sebesar 89\%. Pada perendaman 15 hari efisiensi tertinggi didapat pada ekstrak daun rambutan dengan konsetrasi 150 ppm yaitu sebanyak 96\% dan efisiensi terendah didapat pada ekstrak daun rambutan dengan konsentrasi 50 ppm sebesar $93 \%$.

Persen efisiensi inhibisi meningkat sejalan dengan meningkat nya konsentrasi yang ditambahkan. Persen efisiensi imhibisi tertinggi diperoleh sebesar 96\% dengan penambahan tanin sebesar $150 \mathrm{ppm}$ dengan waktu perendaman selama 15 hari. Laju korosi terendah diperoleh pada konsentrasi inhibitor $150 \mathrm{ppm}$ dan variasi waktu perendaman selama 15 hari yakni sebesar 0,46 .

\section{Kesimpulan dan saran}

Adapun kesimpulan yang di dapatkan dari hasil penelitian yang telah dilakukan adalah, ekstrak daun rambutan mempunyai sifat inhibisi korosi yang cukup baik untuk menurunkan laju korosi, semakin tinggi konsentrasi ekstrak daun rambutan dan lamanya waktu perendaman, maka akan memberikan laju korosi yang lebih rendah, penghambatan laju korosi oleh ekstrak daun rambutan akibat teradsorpsi senyawa-senyawa organik dipermukaan logam, laju korosi dan efisiensi inhibitor terbaik terdapat pada konsentrasi ekstrak daun rambutan sebanyak 150 ppm dengan perendaman dengan media selama 15 hari sebanyak 0,46 dan 96\%. Adapun saran yang di dapatkan dari hasil penelitian yang telah dilakukan adalah, variasi temperatur tidak dilakukan karena keterbatasan waktu, hal ini menjadi pertimbangan dalam penelitian selanjutnya, dalam penelitian ini pengukuran laju korosi berasarkan metode kehilangan berat, untuk penelitian 
selanjutnya diharapkan dapat dilakukan secara elektrokimia, analisa komposisi kimia ekstrak daun rambutan dan analisa mikro tidak dapat dilakukan karena keterbatasan alat, ini pun menjadi pertimbangan dalam penelitian selanjutnya.

\section{Daftar Pustaka}

1. Bushan, A., Hidayatulloh, S., Hendaryati, H., \& Aisyah, I. S. (2017). Analisa Pengaruh Ekstrak Kulit Buah Naga Sebagai Green Inhibitor Corrosion Pada Laju Korosi Baja St-42. 1-9.

2. Hermawan, S., Rizky, Y., Nasution, A., \& Hasibuan, R. (2012). Penentuan Efisiensi Inhibisi Korosi Baja Menggunakan Ekstrak Kulit Buah Kakao ( Theobroma Cacao ). 1(2), 31-33.

3. Mulyati, B. (2019). Tanin Dapat Dimanfaatkan Sebagai Inhibitor Korosi. Jurnal Industri, Elektro, Dan Penerbangan, 8(1), 1-4.

4. Noor, T., W, S. K., Purniawan, A., K, B. A., \& Sulistijono. (2015). Pengaruh Penambahan Ekstrak Kulit Buah Jeruk Dan Kulit Buah Mangga Sebagai Inhibitor Korosi Pada Baja Karbon Dalam Media Nacl 3,5\%. Jurnal Sains Materi Indonesia, 17(1), 29-33.

5. Pratama, M., Razak, R., \& Rosalina, V. S. (2019). Analisis Kadar Tanin Total Ekstrak Etanol Bunga Cengkeh (Syzygium Aromaticum L.) Menggunakan Metode Spektrofotometri Uv-Vis. Jurnal Fitofarmaka Indonesia, 6(2), 368-373. Https://Doi.Org/10.33096/Jffi.V6i2.510

6. Setyowati, L. A., Dimarzio, G., \& Astuti, D. H. (2020). Aplikasi Ekstrak Kulit Buah Nanas Sebagai Inhibitor Korosi Pada Baja Di Lingkungan Nacl $3,5 \%$.01(2), 1-6. 